\title{
The Population Census in Austria
}

\author{
Richard Gisser ${ }^{\star}$
}

Based on the Constitution, the Population Census in Austria is a matter of the central state, serving many political-administrative, planning, research, and other purposes. After its start as a systematic operation in the middle of the 18th century, it developed further by a modern legal basis in 1857 and advances in statistical technology in 1890 (punch cards) and 1971 (machinereadable questionnaires). In the second half of the 20th century, the Population Census became a comprehensive operation, including dwellings, buildings, and workplaces. The communes organized the classical method of on the spot household data collection on behalf of the state. The register-based Census replaced the household collection in 2011. Following a government decision of 2000 , which aimed at the sole use of available micro-data, the first steps for creating the necessary administrative and statistical registers took place in conjunction with the last traditional census of 2001. With new provisions for linking the records, the Register Census Act of 2006, and a full test census in the same year, the new methodology was established and evaluated in a short period. The first regular Register Census "took place" with reference date 31 October 2011. It is described in the central part of this communication, featuring the advantages, strengths, and weaknesses, the backbone registers, the "comparison registers," and the redundancy principle, which help to ensure high data quality and the fit of the census into the international framework. Current developments include the annual update of results, changes and improvements in the data sources, and a short outlook on the next census of 2021.

Keyword: Population Census. Register(-based) Census. Administrative records. Record linkage. Data protection. Statistics. Austria.

\footnotetext{
*Vienna Institute of Demography, Austrian Academy of Sciences Wittgenstein Centre (IIASA, VID/ÖAW, WU), Viena, Austria (richard.gisser@oeaw.ac.at; https://orcid.org/0000-0003-1323-5573).
} 


\section{Introduction}

The issue of the Population Census (Volkszählung) is an object of the Austrian Federal Constitution, and both its legislation and execution fall within the sole competence of the federation. Within the Federal Government, it is the responsibility of the Ministry of Interior. Some of the most crucial census results are the number of inhabitants and the number of Austrian citizens of each political-administrative unit. The former allows for the correct allocation of tax funds (financial equalization or revenue sharing) to the nine Austrian provinces and about 2,000 communes. The latter helps assign seats in the two chambers of the national parliament as well as in the provincial parliaments to the respective constituencies. Furthermore, the census serves a plethora of other administrative, planning, business, scientific, and educational purposes, including international comparisons.

\section{Abridged history}

Census-type data collections in the Habsburg Empire date back to the end of the 17th century but were localized and uneven. Empress Maria Theresia ordered the first census systematically covering the whole territory in 1754 and another one in 1762 . However, this standard was impossible to maintain. In the period leading to the 1848 revolution, mainly so-called conscriptions based on decree took place every three years. The central statistical service was founded in 1829.

The modern era started with the censuses of 1857 and 1869, which were performed based on a census law at a single reference date throughout the national territory. Then, until the First World War, censuses took place every ten years at the end of the years ending in zero $(1880,1890,1900$, and 1910). The Austro-Hungarian Empire was among the leading countries regarding statistics and census-taking. Already at the 1890 census, the data collection in the field was processed separately, using punch cards and electric counting machines, thus enabling flexible tabulation.

The first two censuses after WWI reflect the difficulties faced by the new Republic of Austria, which had become a small state. An extraordinary census on the forward date of 31 January 1920 yielded an undercount, and that of March 1923 suffered from incomplete processing due to lack of money. The census scheduled for 1930 had to be shifted to March 1934 and was the first complete census since 1910. The next census took place in May 1939 when Austria, through annexation, was a part of Germany.

After WWII, Austria became an independent republic, and censuses once again took place every ten years (1951 to 2001). There were various changes in the legal basis e.g., the collection of data on housing grounded no longer on the Population Census Act but a separate decree - as well as extensions in scope (inclusion of buildings in 1971 and workplaces in 1981). Despite the different legal bases, the comprehensive census operations took place jointly. The fieldwork was the task of the communes, which operated 
in close cooperation with the National Statistical Office and received financial compensation for their effort. The processing of machine-readable self-administered questionnaires started in 1971.

In the modern history of the Austrian population censuses, the scope of topics developed gradually to include more variables. To give a few examples: Literacy was introduced in 1880, level of education in 1951 (in 1923 limited to higher education and only one region), subject area of education and training in 1951, daily and non-daily commuting as well as place (commune) of work in 1961. In the 19th century, occupation and industry were considered a single variable, were cross-tabulated at first in 1910 and coded based on separate classifications from 1934 onward. Besides, the concept of population changed over time. In the census of 1857 , most of the available tables were restricted to natives, excluding non-locals from other parts of the country and abroad. From 1869, the census used the concept of present-in-area-population, which was replaced by resident population in 1934.

In June 2000, the Federal Government decided to conduct the "comprehensive census" in 2011 as a register count. Therefore, the first preparatory work took place already in the 2001 census to establish appropriate administrative registers or statistical registers. The new census concept, the Register Census Act, was passed by Parliament in March 2006. By 31 October 2006, a test census was carried out the full extent of a register census. In the following month, an accompanying survey with a $3 \%$ area sample took place for control purposes.

The Register Census Act 2006 defines the method and features of the data collection, as well as the deadlines for the provision of results. The protection of personal data deserves special attention. Thanks to the e-Government law, registers may be linked and maintain data protection, with the help of the so-called sector-specific personal identifier Official Statistics (bPK-AS), which is generated by the Data Protection Authority. This identifier makes no conclusions on the possible person, and the data link is, therefore, without a name.

\section{The register census (Registerzählung) in Austria, 2011}

The 2011 register census marks a turning point in the history of Austrian censuses and replaces the traditional census, the last of which took place in 2001. For the first time, individuals were no longer questioned personally with a household roster and a questionnaire. Nowadays, information comes from registers, which are already kept for administrative purposes. This mode has two major advantages: on the one hand, citizens are relieved from the obligation of completing paper questionnaires, and, on the other hand, the costs are considerably lower than those involved in a traditional census enumeration. Other minor aspects include avoiding difficulties with questions such as religious affiliation, and protests by activists against censuses and statistics. Since the 
introduction of the register census, Austria has been playing a pioneering international role together with the Nordic countries. Few countries have so far conducted a census exclusively based on register data.

Like the previous comprehensive censuses, the 2011 census also consists of a population census, a census of workplaces as well as a building and housing census. The results present numerical portraits of the structure and dynamics of the entire population, households and families, workplaces, and companies as well as buildings and apartments in Austria. Their high strength is the comprehensive and comparable data at the smallest territorial level. The results of the 2001 census are comparable with the results with those of previous years; however, some information is no longer available with the new survey method as it is not part of any of the registers used - e.g., language or religion.

The 2011 register census is a full enumeration based on data from existing administrative registers, which means that all variables for the census come from registers. The basis for all personal, household and family characteristics are provided on the one hand by the central register of inhabitants (Zentrales Melderegister - ZMR), which was established during the 2001 census already with a view of preparing for the register census. All persons living in Austria with main and secondary residence have to enroll in this electronic directory. The registers also include data from the social security funds, tax system, labor market service, educational attainment register, and school and university attendance statistics. The base registers for the workplace census are the business enterprise register and the agricultural and forestry register; for the building and housing census, it is the building and housing register. In sum, all the features and characteristics that are collected for the census come from these basic or backbone-registers.

The features and characteristics are checked for accuracy and completeness with the help of numerous "comparison registers" to assure high data quality. Altogether, about 40 sources of micro-level data serve this purpose. For the case of existing redundant information about features from the various data sources, there are rules after an in-depth analysis that allows for the final feature value to be specified. The comparison data come from registers about foreigners, federal and state employees, social assistance, family allowances, military and alternative service, and vehicle admissions. The principle of redundancy is a peculiarity of the Austrian register census; it compensates for quality losses through imperfect registers and ensures high-quality results.

The three parts of the register census - population, workplace, and building and housing census - are connected by the object number of the building and housing register. With the help of the bPK-AS and the employer number of the Social Security Institutions (HV-ID), individuals in the labor force are linked to the business enterprise register and, thus, the workplace census. All information refers to the same day, namely 31 October 2011.

The catalog of variables as well as their concepts, structure, and definitions ground on the Recommendations for Population and Housing Censuses of the United Nations Economic Commission for Europe (UNCE, 2006). For the Austrian register census of 2011 , 
the recommendations for the 2010 round of population and housing censuses applied. In the European Union, all population and housing censuses took place in the same year (2011) according to uniform criteria, which ensures comparability with the other EU and the EFTA member states. The results of the national censuses had to be delivered by March 2014 to Eurostat, where a Census Hub was established. The legal EU basis for the 2011 round was Regulation n. 763/2008 of the European Union, from July 9, 2008, concerning population and housing censuses.

The approximate magnitudes of the different statistical universes as of 31 October 2011 were: Austrian resident population of 8.4 million people, including 7.5 million Austrian citizens; 700,000 workplaces, 620,000 companies; 2.2 million buildings and 4.4 million apartments (dwellings). The standard territorial breakdown of results is by province, district, and commune. There are special evaluations for census tracts, localities, and statistical grids. The schedule for the public presentation of the results was: preliminary population count on December 1, 2011; final number of population and citizens on June 21, 2013, and detailed results on November 4, 2013.

\section{Current developments}

The new method of the register-based census has proven itself after the 2006 test count, the 2011 register census, and will continuein the future. Register data on persons and employment have been available since 2008, as part of the Adjusted Employment Statistics (AES). Since 2011, a workplace census has been published annually from registers, as well as family and household characteristics. The population for the AES is that of the annual statistics of the population, following the Financial Equalization Act. Revenue sharing between territorial collectivities is updated every year, rather than every ten years, as was the case in the past.

The annual implementation of the AES helps constantly check and improve the quality of data between register censuses. Conceptual changes in the data sources are incorporated regularly, as well as new data sources such as the central civil status register that exists since November 2014, which helps to improve the quality of marital status information and family and household statistics. Regarding education statistics, the classification changed to ISCED 2011. Furthermore, the quality of data on immigrant educational attainment is increasing due to the higher proportion of nostrification and recognition of educational qualifications acquired abroad. There will be an improvement in the quality of the destination statistics for commuters abroad (frontier workers) by including tax data. Since the building and housing registries increasingly serve as the basis for administrative operations (such as unit value determination), the quality of building and housing census data will also improve.

It is only logical that changes in the administrative data sources demand an adaptation of the register census law. This legislative process will start in good time before the next census day (31 October 2021). 


\section{Reference}

UNECE - United Nations Economic Commission for Europe. Conference of the European Statisticians Recommendations for the 2010 Censuses of Population and Housing. Prepared in cooperation with the Statistical Office of the European Communities (EUROSTAT). New York and Geneva: United Nations, 2006. Available at: https://www.unece.org/fileadmin/DAM/stats/ publications/CES_2010_Census_Recommendations_English.pdf.

\section{About the author}

Richard Gisser is Demographer, Ph.D.

\section{Contact address}

Welthandelsplatz 2, Level 2

1020 - Vienna, Austria

\section{Resumo}

\section{Os censos de população na Áustria}

Baseado na Constituição, o Censo Populacional na Áustria é uma questão do governo central e serve a muitos propósitos político-administrativos, de planejamento e pesquisa, entre outros. Após seu início, como uma operação sistemática, em meados do século XVIII, ele foi aperfeiçoado devido a uma nova base legal, em 1857, e aos avanços na tecnologia estatística, em 1890 (cartões perfurados) e 1971 (questionários lidos por máquinas). Na segunda metade do século XX, o censo populacional tornou-se uma operação abrangente, incluindo habitações, domicílios e locais de trabalho. 0 método clássico de coleta de dados no próprio domicílio, organizado pelos municípios em nome do Estado, foi substituído pelo censo baseado em registros, em 2011. Seguindo uma decisão governamental de 2000, cujo objetivo era o uso exclusivo dos microdados disponíveis, os primeiros passos para a criação dos registros administrativos e estatísticos necessários ocorreu conjuntamente com o último censo tradicional, de 2001. Com novas disposições para parear os registros, a Lei do Censo de Registros de 2006 e um censo-teste completo no mesmo ano, a nova metodologia foi definida e avaliada em um curto período. O primeiro censo de registro teve como referência 31 de outubro de 2011. Sua descrição, na parte principal deste texto, apresenta as vantagens, os pontos fortes e fracos, os registros mais relevantes ("espinha dorsal"), os registros de comparação e o princípio da redundância, que ajudam a manter a qualidade dos dados e adequação do censo ao arcabouço internacional. Desenvolvimentos atuais incluem atualizações anuais dos resultados, mudanças e melhorias nas fontes de dados. É apresentado, também, um breve panorama do próximo censo, em 2021.

Palavras-chave: Censo populacional. Censo baseado em registros. Registros administrativos. Pareamento de registros. Proteção de dados. Estatísticas. Áustria. 


\section{Resumen}

Los censos de población en Austria

Sobre la base de la Constitución el censo de población es un asunto estatal central en Austria, con arreglo a diversos fines politicoadministrativos, de planificación e investigación, entre otros. Luego de haber comenzado como operación sistemática a mediados del siglo XVIII, se desarrolló luego como sobre bases legales modernas en 1857 y avanzó en tecnología estadística en 1890 (tarjetas perforadas) y en 1971 (cuestionarios legibles por máquinas). En la segunda mitad del siglo XX el censo de población se convirtió en una operación integral que incluyó vivienda, edificios y lugares de trabajo. El método clásico de recolección de datos en el punto en los hogares, organizado por las comunas a expensas del Estado, fue reemplazado por el censo basado en registro de 2011. A consecuencia de una decisión de gobierno del año 2000, que tenía como objetivo el uso exclusivo de los microdatos disponibles, el primer paso para la creación de los registros administrativos y estadísticos necesarios se llevó a cabo junto con el último censo de tipo tradicional de 2001. Con nuevas provisiones para vincular los registros, el Acto de Registro del Censo de 3006 y una prueba completa de censo en el mismo año, la nueva metodología se estableció y evaluó en un período muy corto. El primer censo de registro regular «tuvo lugar» con datos de referencia el 31 de octubre de 2011. Es descripto en la parte principal de su comunicación, donde se presentan sus ventajas, fortalezas y debilidades, así como sus registros principales, los registros «de comparación» y el principio de redundancia, que ayudan a asegurar datos de alta calidad y el ajuste del censo al marco de referencia internacional. Hoy, los desarrollos incluyen la actualización anual de los resultados, los cambios y mejoras en las fuentes de datos y una breve mirada hacia el nuevo censo de 2021.

Palabras clave: Censo de población. Censos basados en registros. Datos administrativos. Vinculación de registros. Protección de datos. Estadísticas. Austria.

Received for publication in $07 / 10 / 2019$

Approved for publication in 14/10/2019 